\title{
EFFECTS OF INTERRUPTING AND RESTORING THE CIRCULATION TO THE LOWER EXTREMITIES ${ }^{1}$
}

\author{
By D. DAUBER, M. LANDOWNE,2 L. N. KATZ, AND H. WEINBERG \\ (From the Cardiovascular Department of Michael Reese Hospital, Chicago)
}

(Received for publication August 12, 1941)

It has been established that the heart accelerates on release of tourniquets previously applied to the extremities $(2$ to 9,13$)$. The mechanism for this acceleration has not been adequately explained.

Jarisch and Gaisböck (12) have postulated a reflex origin of this acceleration, but offered no supporting evidence. They anticipated a blood pressure fall simultaneous with the rise in heart rate but obtained no evidence of the former with the auscultatory method. Asmussen, Christensen and Nielsen $(5,13)$ noted that the cardiac acceleration was greatest when the subject was in the upright posture and least in the head-down position. The release of the tourniquet, they found, produced a drop in both systolic and diastolic pressure, the magnitude of the pressure drop likewise varying with posture. They considered the acceleration a reflex compensatory to the blood pressure fall, and they attributed the latter to stimulation of "pressor-sensitive zones" assumed to exist in the large limb arteries. Alam and Smirk $(1,2)$ attributed the cardiac acceleration to the release into the blood stream of metabolites arising from the previously occluded extremities.

In order to study this phenomenon further, a series of experiments was carried out in which the relation of the cardiac acceleration to changes in accurately recorded arterial and venous pressure was determined. The influence of altering several variables on the magnitude of cardiac acceleration was also determined. In the course of this study, opportunity was afforded for measuring some of these circulatory changes occurring on application of and during arterial and venous occlusion as well as following their release. These are described in the report and their bearing on the major purpose of the presentation is indicated.

\section{METHOD}

Thirty-one subjects were studied. Twenty-seven were selected as normal young adults (physicians, technicians

1 Aided by the A. D. Nast Fund and the Isaac and Kate Meyer Fund.

2 Emanuel Libman Fellow. and convalescent surgical patients) from 16 to 35 years of age; twenty-five of them were males and two females. The other four subjects had moderately advanced thromboangiitis obliterans and ranged in age from 32 to 52 years.

All observations were made on recumbent subjects after a rest period of 15 to 30 minutes in a warm, quiet and darkened room. While the conditions were not basal, they were sufficiently stable to eliminate most of the extraneous factors which might influence heart rate, as is demonstrated by the small magnitude of the spontaneous pulse rate changes in the control period (Table I). At the beginning of the rest period, electrodes lead-

TABLE I

Changes in heart rate on release of bilateral arterial occlusion

\begin{tabular}{|c|c|c|c|c|c|c|c|c|}
\hline \multirow{2}{*}{ Subject } & \multirow{2}{*}{$\begin{array}{c}\text { Maxi- } \\
\text { mum } \\
\text { rest- } \\
\text { ing } \\
\text { varia- } \\
\text { tion }\end{array}$} & \multirow{2}{*}{$\begin{array}{c}\text { Maxi- } \\
\text { mum } \\
\text { rise } \\
\text { on re- } \\
\text { lease }\end{array}$} & \multicolumn{2}{|c|}{$\begin{array}{c}\text { Time of } \\
\text { onset of } \\
\text { acceleration }\end{array}$} & \multicolumn{2}{|c|}{$\begin{array}{c}\text { Time of } \\
\text { peak of } \\
\text { acceleration }\end{array}$} & \multicolumn{2}{|c|}{$\begin{array}{l}\text { Time of } \\
\text { return to } \\
\text { resting level }\end{array}$} \\
\hline & & & Beat & $\begin{array}{l}\text { Sec- } \\
\text { ond }\end{array}$ & Beat & $\begin{array}{l}\text { Sec- } \\
\text { ond }\end{array}$ & Beat & Second \\
\hline $\begin{array}{l}\text { MF } \\
\text { MF } \\
\text { MF } \\
\text { MF } \\
\text { EK } \\
\text { EK } \\
\text { EK } \\
\text { Ca } \\
\text { Ca } \\
\text { G } \\
\text { Ka. } \\
\text { Br } \\
\text { Cr }\end{array}$ & $\begin{array}{c}\begin{array}{c}\text { beats } \\
\text { per } \\
\text { minute }\end{array} \\
10 \\
11 \\
8 \\
7 \\
15 \\
13 \\
14 \\
4 \\
4 \\
7 \\
10 \\
10 \\
10\end{array}$ & $\begin{array}{c}\text { beats } \\
\text { per } \\
\text { minute } \\
18 \\
15 \\
35 \\
29 \\
25 \\
15 \\
13 \\
13 \\
17 \\
25 \\
14 \\
>20 \\
20\end{array}$ & $\begin{array}{l}1 \\
1 \\
1 \\
2 \\
2 \\
2 \\
5 \\
3 \\
5 \\
3 \\
2 \\
2 \\
1\end{array}$ & $\begin{array}{l}0.8 \\
0.8 \\
1.0 \\
0.9 \\
0.8 \\
0.9 \\
3.1 \\
1.5 \\
2.8 \\
2.1 \\
1.0 \\
1 \\
1.1\end{array}$ & $\begin{array}{r}10 \\
8 \\
7 \\
7 \\
11 \\
6 \\
11 \\
10 \\
26 \\
12 \\
7 \\
7 \\
14\end{array}$ & $\begin{array}{c}7 \\
6 \\
5 \\
5 \\
7.5 \\
5.9 \\
6.8 \\
5 \\
15 \\
7 \\
5 \\
5 \\
12\end{array}$ & $\begin{array}{r}\text { ca. } 115 \\
>29 \\
18 \\
16 \\
20 \\
20 \\
21 \\
67 \\
48 \\
31 \\
13 \\
31 \\
19\end{array}$ & $\begin{array}{l}75 \\
>20 \\
13.5 \\
12 \\
13.5 \\
20 \\
15 \\
35 \\
27 \\
17.5 \\
8 \\
22 \\
15\end{array}$ \\
\hline Average & 9.5 & 20 & 2.3 & 1.4 & 10.5 & 6.3 & 28 & 23 \\
\hline
\end{tabular}

ing to an electrocardiograph were strapped on the wrists, and wide leather-backed pneumatic cuffs were placed about both upper thighs. Abrupt inflation of these cuffs was achieved by suddenly connecting them to a pressure tank previously set at the desired pressure level. This avoided congestion of the legs. Such occlusion was usually unaccompanied by pain even when pressures of 300 $\mathrm{mm}$. $\mathrm{Hg}$ were used. Deflation of the cuffs was likewise brisk. In all new subjects, trials were carried out to familiarize them with the sensations involved in the procedure.

Pressure over $200 \mathrm{~mm}$. $\mathrm{Hg}$ was used to ensure almost complete arterial obstruction (19). The only sensation 
noted during the period of occlusion was a feeling of warmth in the limbs, which increased to an unpleasant sense of heat when the constriction was prolonged. During the occlusions, which were rarely over 15 minutes in duration, several of the subjects actually dozed. On restoration of blood flow, a transient sensation of coolness was experienced, succeeded by a wave of warmth flowing down the limbs and then by tingling and numbness. These subjective phenomena were accompanied by visible hyperemia.

In the preliminary experiments, the pulse rate was measured by palpating the radial artery for 30 -second periods timed by a stopwatch. In the main group of experiments, the electrocardiograph, with the camera speed reduced to $6 \mathrm{~mm}$. per second, was used to record heart rate. Further, in a group of 13 tests, the ordinary camera speed of $25 \mathrm{~mm}$. per second was used in order to follow instantaneous heart rate from beat to beat (60/individual cycle length in seconds). For the most part heart rate was recorded for the first 15 seconds of each minute during the rest periods and during maintained occlusion, and the rate per minute calculated by multiplying by 4 the number of beats and fractions thereof in this 15-second interval. Recording was begun 30 seconds before and continued until 45 seconds after the act of application or release of occlusion. The rate per minute was arrived at as above, except in those experiments in which the cycle length from beat to beat was measured. At least 5 minutes were allowed between successive occlusions to permit the heart rate to return to its resting level.

In 6 preliminary observations, blood pressure was measured by the auscultatory method. In the remainder (7 experiments) the brachial pressure was recorded optically by intraarterial puncture with the Hamilton needle manometer (10). Femoral venous pressure was also recorded by an optical manometer (15).

\section{RESULTS}

1. The cardiac acceleration on release of arterial occlusion of the limbs. The data from 13 experi- ments on seven normal subjects in which the heart rate was measured cycle by cycle is assembled in Table I and typical responses are shown in Figures 1 and 5. A transitory increase in heart rate occurred uniformly on release of occlusion. It was longer in duration and greater than the variation in rate in the control periods which results from sinus arrhythmia.

In 52 bilateral arterial occlusions in four normal subjects, average rates measured over 15 -second intervals were calculated. It was found that the average cardiac acceleration on release was 15 beats per minute for an average duration of 1.5 minutes. In 26 other observations in which heart rate was measured by radial artery palpation, the cardiac acceleration on release averaged 11 beats per minute.

2. The blood pressure changes on release of arterial occlusion of the limbs. The data of 7 experiments on four normal subjects in whom intraarterial pressure was recorded on release of occlusion are shown in Table II, and Figure 1 illustrates the time course in a typical experiment. A precipitous blood pressure fall at the instant of cuff deflation occurred in every instance, with one exception in which the drop was delayed 1 second. Systolic and diastolic pressure changes were parallel in all instances. The magnitude of these drops was significantly greater than the maximum resting variation in blood pressure in any given case. The fall in pressure increased with the duration of occlusion ( $c f$. Table II).

In 5 of the 7 experiments listed in Table II, measurements were made of the instantaneous

TABLE II

Effect on brachial intraarterial pressure and heart rate of release of bilateral arterial occlusion

\begin{tabular}{|c|c|c|c|c|c|c|c|c|}
\hline Subject & $\begin{array}{l}\text { Duration of } \\
\text { occlusion }\end{array}$ & $\begin{array}{c}\text { Maximum } \\
\text { blood } \\
\text { pressure } \\
\text { variation } \\
\text { at rest* }\end{array}$ & $\begin{array}{l}\text { Maximum } \\
\text { systolic } \\
\text { pressure } \\
\text { decrease on } \\
\text { release }\end{array}$ & $\begin{array}{l}\text { Maximum } \\
\text { diastolic } \\
\text { pressure } \\
\text { decrease on } \\
\text { release }\end{array}$ & $\begin{array}{c}\text { Maximum } \\
\text { decrease in } \\
\text { dicrotic } \\
\text { notch } \\
\text { level on } \\
\text { release }\end{array}$ & $\begin{array}{c}\text { Duration of } \\
\text { blood } \\
\text { pressure } \\
\text { drop }\end{array}$ & $\begin{array}{l}\text { Time of onset } \\
\text { of blood pressure } \\
\text { drop }\end{array}$ & $\begin{array}{l}\text { Time of } \\
\text { onset of } \\
\text { pulve } \\
\text { acceleration }\end{array}$ \\
\hline $\begin{array}{c}\text { EK } \\
\text { EK } \\
\text { EK } \\
\mathbf{G} \\
\text { Ka. } \\
\text { Kr. } \\
\text { Kr. } \\
\text { Average }\end{array}$ & $\begin{array}{c}\text { minutes } \\
1 \\
2 \\
6 \\
7 \\
15 \\
16 \\
21\end{array}$ & $\begin{array}{c}\text { mm. } \mathrm{Hg} \\
6 \\
7 \\
8 \\
4 \\
5 \\
15 \\
20 \\
9\end{array}$ & $\begin{array}{c}\text { mm. } \boldsymbol{H g} \\
10 \\
11 \\
14 \\
16 \\
17 \\
27 \\
38 \\
19\end{array}$ & $\begin{array}{c}m m . H g \\
11 \\
10 \\
10 \\
13 \\
14 \\
14 \\
27 \\
14\end{array}$ & $\begin{array}{c}\text { mm. } \boldsymbol{H g} \\
20 \\
20 \\
25 \\
30 \\
29 \\
? \\
25 \\
25\end{array}$ & $\begin{array}{c}\text { seconds } \\
12 \\
11 \\
30 \\
15 \\
>20 \\
>10 \\
>25 \\
18\end{array}$ & $\begin{array}{c}\text { seconds } \\
\text { Instantaneous } \\
\text { Instantaneous } \\
\text { Instantaneous } \\
1 \\
\text { Instantaneous } \\
\text { Instantaneous } \\
\text { Instantaneous }\end{array}$ & $\begin{array}{c}\text { seconds } \\
0.9 \\
3.1 \\
0.8 \\
2.1 \\
1 \\
? \\
? \\
1.6\end{array}$ \\
\hline
\end{tabular}

* Systolic or diastolic. 


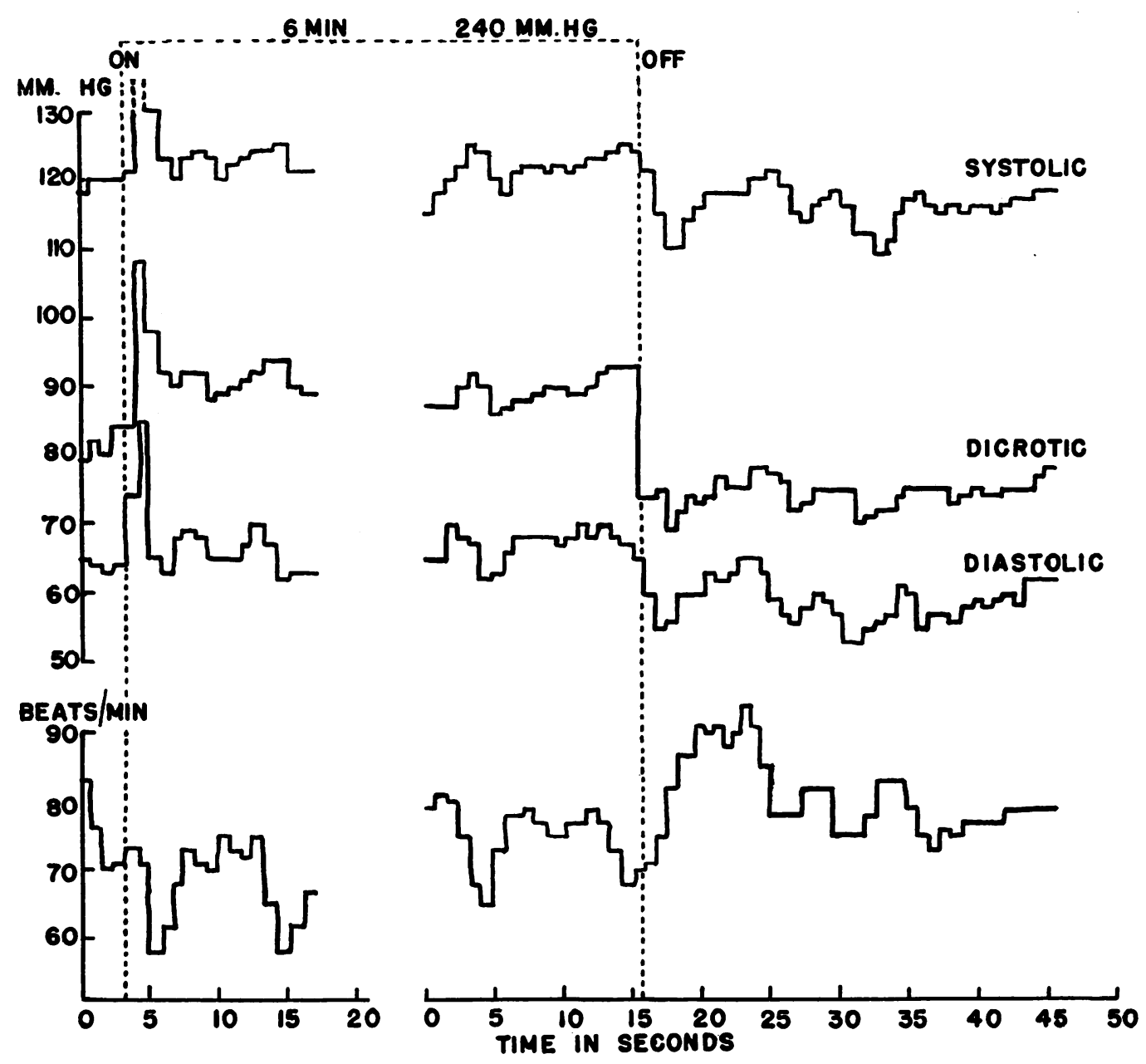

Fig. 1. A Typical Response in Blood Pressure and Heart Rate on Application and on Release of Bilateral Arterial Occlusion of the Lower Extremities in a Normal Subject

Blood pressure was recorded with the Hamilton needle manometer in the brachial artery, and heart rate recorded with the electrocardiograph at camera speed of $2.5 \mathrm{~cm}$. per second.

heart rate changes and in every instance the cardiac acceleration did not occur until 0.8 to 3.1 seconds after the blood pressure fell.

Simultaneously with the pressure drop, the pulse contour changed, reflecting the lowering of peripheral resistance (Figure 2). The change consisted in a lowering of the level of the dicrotic notch, an increased celerity to the early part of the catacrotus and a smoothing out of the summit of the curve. The drop in level of the dicrotic notch was greater than that of the systolic and diastolic pressures ( $c f$. Figure 2 and Table II).

3. The relation of the acceleration on release to the duration of the previous occlusion of the limbs. The degree of acceleration of the heart rate varied directly with the duration of prior occlusion. This relationship is summarized in Figure 3 which presents the total rise in heart rate. The rough proportionality between the cardiac acceleration on release and the duration of prior occlusion applied for periods of occlusion of from 3 to 15 minutes is made more evident by considering the integrated increase in rate than from observation of either maximum increase or duration of increase alone. Short occlusions of $1 / 4$ to $2 \mathrm{~min}$ utes were followed by pulse accelerations, but the magnitude was within the range of resting variation. They were, however, consistent in occurrence and persisted longer than the resting variations, suggesting that they were significant. Oc- 

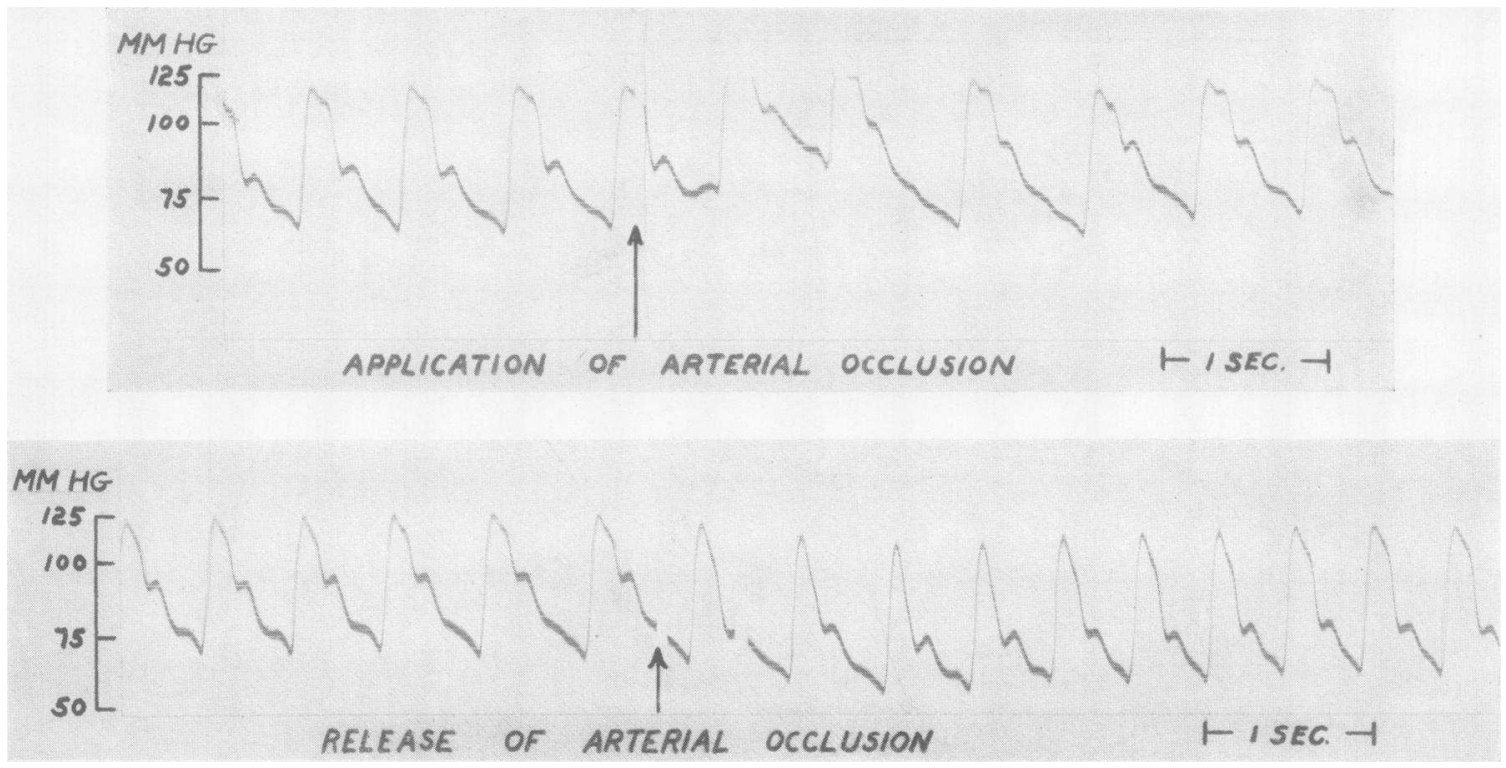

Fig. 2. A Typical Record of Blood Pressure in the Brachinl Artery on Application and on Release of

Bilateral Arterial Occlusion in the Normal Subject, Recorded With Hamilton Needle Manometer

The arrows point to the interruption in the beam which signaled the instant of application and release.

clusions of over 15 minutes produced pain and thereby an acceleration in heart rate during the later minutes of occlusion, masking the acceleration following release of occlusion.

4. The changes in venous pressure in the femoral vein following release of the arterial occlusion, and their time relation to the cardiac acceleration. In two trained subjects 4 observations were made by optically recording the femoral venous pressure during and after release of arterial occlusion. A typical result is shown in Figure 4 and the data are summarized in Table III. During arterial occlusion the femoral venous pressure fell. After a lag of 3 to 9 seconds following release, there was a slight rise, reaching a maximum value, approximately at the resting level, within 13 to 40 seconds.

TABLE III

Femoral venous pressure upon release of arterial occlusion

\begin{tabular}{l|c|c|c|c|c}
\hline \hline Subject & $\begin{array}{c}\text { Initial } \\
\text { resting } \\
\text { femoral } \\
\text { venous } \\
\text { pressure }\end{array}$ & $\begin{array}{c}\text { Pressure } \\
\text { at end of } \\
\text { occlusion } \\
\text { period }\end{array}$ & $\begin{array}{c}\text { Maximum } \\
\text { pressure } \\
\text { after } \\
\text { release }\end{array}$ & $\begin{array}{c}\text { Time } \\
\text { when rise } \\
\text { begins }\end{array}$ & $\begin{array}{c}\text { Time of } \\
\text { maximum } \\
\text { pressure }\end{array}$ \\
\cline { 2 - 3 } & $\mathrm{cm} . \mathrm{H}_{2} \mathrm{O}$ & $\mathrm{cm} . \mathrm{H}_{2} \mathrm{O}$ & $\mathrm{cm.} \mathrm{H}_{2} \mathrm{O}$ & seconds & seconds \\
$\mathrm{CR}$ & 5.5 & 3.8 & 5.3 & 9 & 40 \\
$\mathrm{CR}$ & 5.3 & 2.5 & 3.3 & 8 & $>28$ \\
$\mathrm{CA}$ & 11.5 & 10.0 & 11.8 & 3 & 13 \\
$\mathrm{CA}$ & 11.5 & 11.0 & 12.2 & 5 & 14 \\
\hline
\end{tabular}

TABLE IV

Effect of release of arterial occlusion (maintained for 3 to 15 minutes) in thromboangiitis obliterans

\begin{tabular}{|c|c|c|c|c|}
\hline $\begin{array}{c}\text { Sub- } \\
\text { ject }\end{array}$ & $\begin{array}{l}\text { Severity of } \\
\text { disease }\end{array}$ & $\begin{array}{l}\text { Maximum } \\
\text { heart rate } \\
\text { variation } \\
\text { at rest }\end{array}$ & $\begin{array}{l}\text { Change in } \\
\text { heart rate on } \\
\text { release of } \\
\text { occlusion of } \\
\text { both legs }\end{array}$ & $\begin{array}{l}\text { Change in } \\
\text { heart rate on } \\
\text { release of } \\
\text { occlusion of } \\
\text { worse leg only }\end{array}$ \\
\hline $\mathrm{SC}$ & + & $\begin{array}{c}\text { beats per minute } \\
8\end{array}$ & $\begin{array}{l}\text { beats per minute } \\
+5 \\
+4,+8 \dagger\end{array}$ & $\begin{array}{c}\text { beats per minute } \\
-3,+7\end{array}$ \\
\hline HS & ++ & 4 & $\begin{array}{l}+10 \\
+\quad 6\end{array}$ & +6 \\
\hline ML & +++ & 6 & +3 & $\begin{array}{l}+4 \\
+4^{*} \\
+4^{*} \\
-7^{*} \\
-3^{*}\end{array}$ \\
\hline MA & ++++ & 7 & $\begin{array}{l}+7 \\
-4 \\
-9^{*} \\
-10^{*} \\
-2,+4 \dagger \\
-2,+4 \dagger \\
-3,+6 \dagger\end{array}$ & $\begin{array}{r}+5^{*} \\
0^{*} \\
-6^{*}\end{array}$ \\
\hline
\end{tabular}

* Pulse rate measured by counting radial pulse for 10 -second periods timed by stopwatch. All other measurements made on electrocardiograph by usual method except in cases where instantaneous pulse rate was measured.

† Instantaneous pulse rate measured.

5. The effect of release of bilateral arterial occlusion on the heart rate in patients with thrombo- 


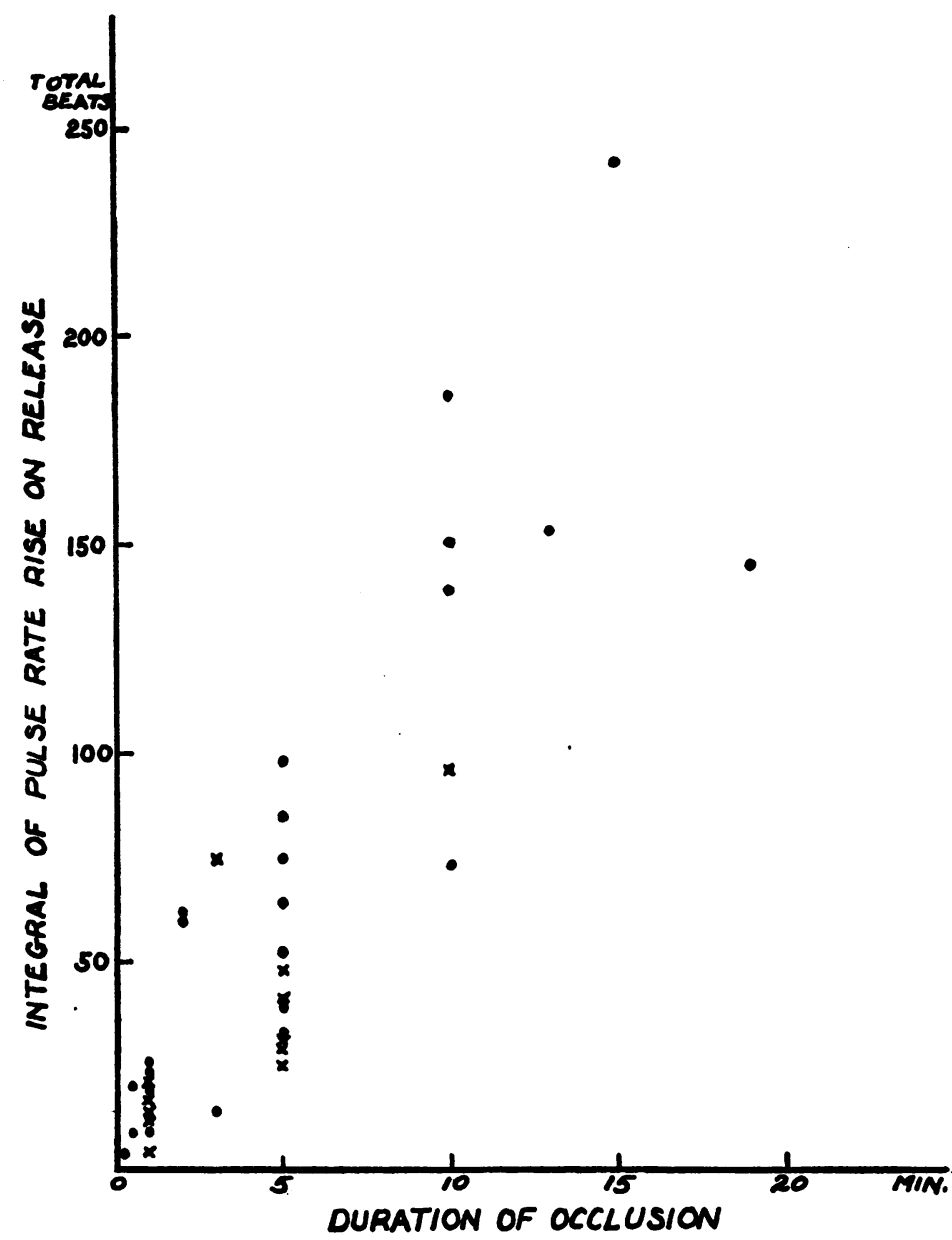

Fig. 3. The Effect of Duration of Prior Occlusion on the Total Rise in Heart Rate (Integral of Rise) Following Release of Bilateral Arterial Occlusion of the Lower Extremities in The Normal Subject

Heart rate was recorded with the electrocardiograph at camera speed of $6 \mathrm{~mm}$. per second. Solid circles designate one subject and crosses a second subject.

angiitis obliterans. The effect of release of arterial occlusion was tested in four patients with moderately advanced thromboangiitis obliterans and the results are summarized in Table IV. Insignificant acceleration occurred when occlusion of the limbs was released, and any slight rise in heart rate tended to occur later than in the normal. The acceleration was greater than the resting variation in only one patient, H. S., who had the least vascular disease. A typical response in a normal subject is compared in Figure 5 with that in a patient with thromboangiitis obliterans. No noticeable change in pulse contour followed release of occlusion in the one subject with thromboangiitis obliterans in whom the brachial intraarterial pressure was recorded (Figure 6). Furthermore, although a pressure drop occurred, it was less abrupt than in normals. The data are shown in Table $\mathrm{V}$ and the results of a typical experiment in Figure 7.

6. Circulatory changes upon application of arterial and venous occlusion. The changes in heart rate on application of arterial occlusion were not as consistent as those following release of occlusion. In 40 instances, application of bilateral arterial occlusion resulted in no significant change in 


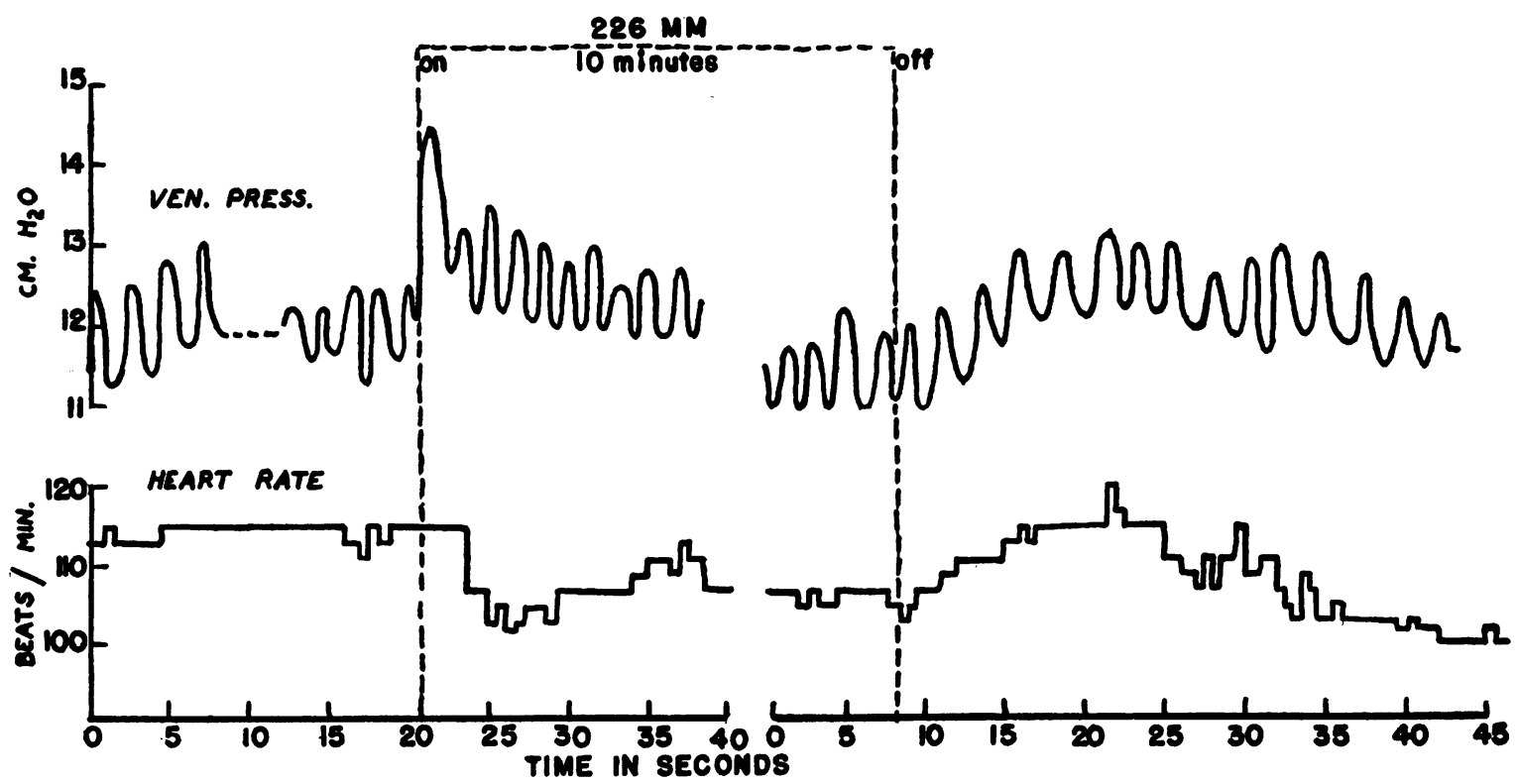

Fig. 4. A Typical Response of femoral Vein Pressure on Application Of, During, and Following Release of Bilateral Arterial Occlusion of the Lower Extremities in a Normal Subject

Chart constructed from optically recorded venous pressure, with a needle in the femoral vein. Heart rate was recorded with the electrocardiograph at camera speed of $2.5 \mathrm{~cm}$. per second. Note the respiratory undulations in venous pressure.

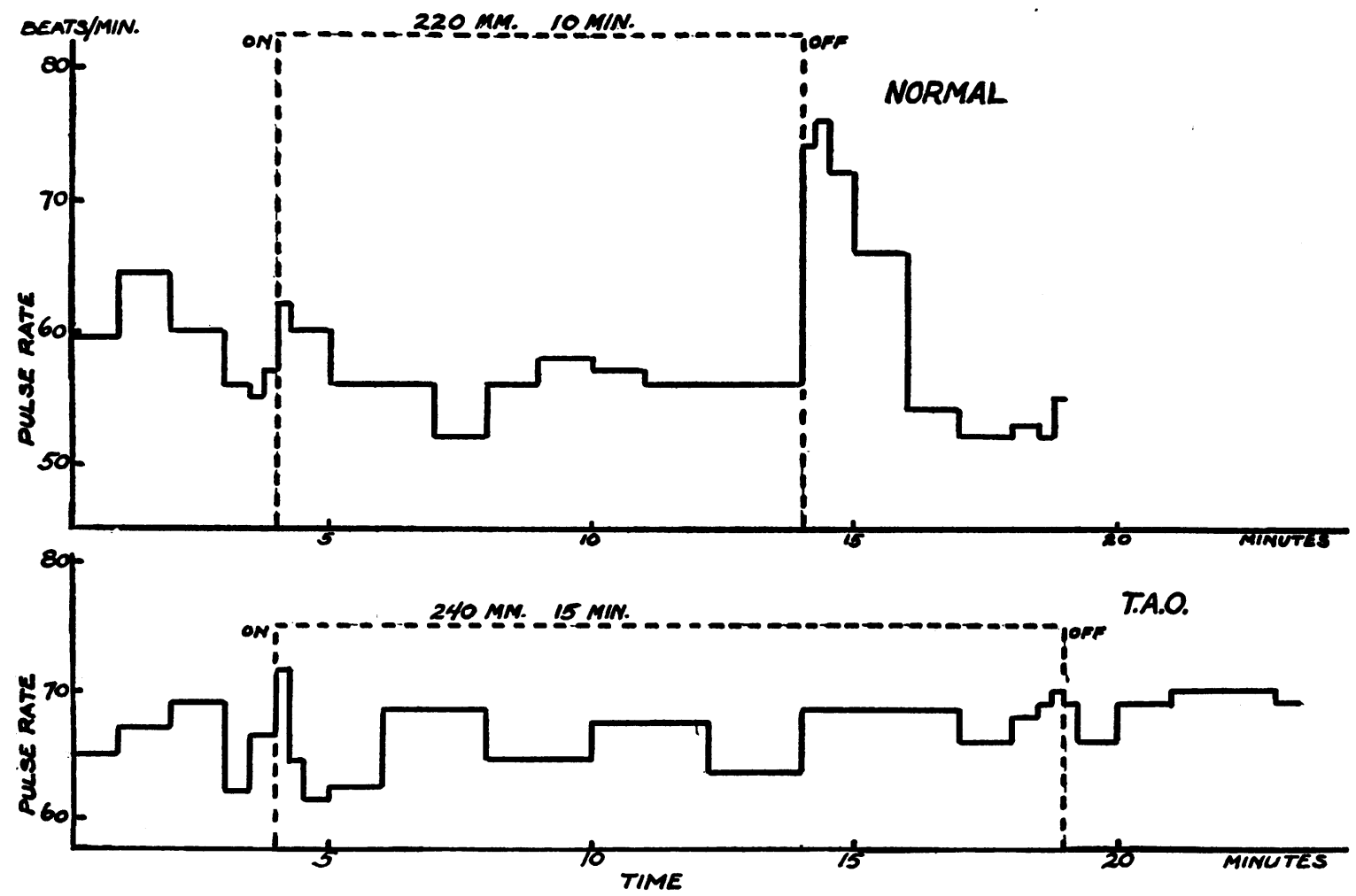

Fig. 5. A Comparison of the Heart Rate Changes in a Normal Subject (Above) and a Patient With Thromboangittis Obliterans (Below) Following Release of Bilateral Arterial Occlusion of the Lower EXTREMities

Heart rate was recorded with the electrocardiograph at camera speed of $6 \mathrm{~mm}$. per second. 


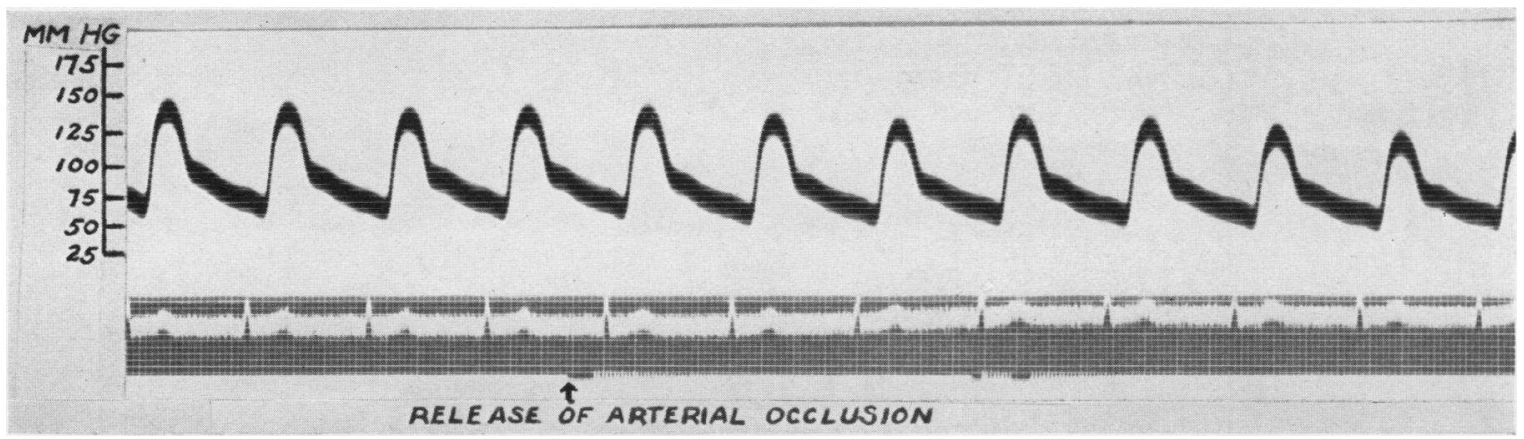

Fig. 6. A Record of the Changes in Blood Pressure on Release of Bilateral Arterial Occlusion of the Lower Extremities in a Patient With Thromboangitis Obliterans

The blood pressure was optically recorded with the Hamilton needle manometer in the brachial artery. Thin time lines on electrocardiogram equal 0.04 second and heavy lines equal 0.2 second. The arrow indicates the instant of release of occlusion, recorded as a dip by the signal magnet.

TABLE V

Brachial intraarterial pressure changes on release of arterial occlusion in one subject with thromboangiitis obliterans

\begin{tabular}{c|c|c|c|c|c|c|c}
\hline \hline $\begin{array}{c}\text { Sub- } \\
\text { ject }\end{array}$ & $\begin{array}{c}\text { Dura- } \\
\text { tion } \\
\text { of } \\
\text { ooclu- } \\
\text { sion }\end{array}$ & $\begin{array}{c}\text { Maxi- } \\
\text { mum } \\
\text { rest- } \\
\text { ing } \\
\text { varia- } \\
\text { tion* }\end{array}$ & $\begin{array}{c}\text { Maximum } \\
\text { fall in } \\
\text { systolio } \\
\text { pressure }\end{array}$ & $\begin{array}{c}\text { Maximum } \\
\text { fall in } \\
\text { diastolic } \\
\text { pressure }\end{array}$ & $\begin{array}{c}\text { Maximum } \\
\text { fall in } \\
\text { level of } \\
\text { dierotic } \\
\text { notch }\end{array}$ & $\begin{array}{c}\text { Time of onset } \\
\text { of blood } \\
\text { pressure } \\
\text { drop }\end{array}$ & $\begin{array}{c}\text { Dura- } \\
\text { tion of } \\
\text { blood } \\
\text { pres- } \\
\text { sure } \\
\text { drop }\end{array}$ \\
\hline & $\begin{array}{c}\text { min- } \\
\text { utes }\end{array}$ & $\begin{array}{c}m m . \\
H g\end{array}$ & $m m . H g$ & $m m . H g$ & $m m . H g$ & seconds & seconds \\
MA & 15 & 10 & 17 & 8 & 11 & 0.8 & $>45$ \\
MA & 10 & 5 & 22 & 14 & 18 & 0.8 & 20 \\
MA & 3 & 9 & 12 & 7 & 8 & Instantaneous & 18.5 \\
\hline
\end{tabular}

* Systolic and diastolic.

heart rate; while in 32 instances the heart rate slowed (Figure 4); and in 7 there was a pulse acceleration ( $c f$. normal in Figure 5). In a number of instances, the acceleration was followed by a distinct slowing to below resting levels. Training failed to produce consistency in these changes.

When the limbs were previously made hyperemic by heat, occlusion caused a more consistent and a greater pulse slowing. Similarly, consistent slowing occurred when occlusion was applied during a period of reactive hyperemia. Slowing was greatest in this last circumstance.

More regular slowing followed application of venous occlusion, with slowing in 7 out of 10 trials.

In contrast to the heart rate, the arterial and venous pressures showed consistent changes on cuff inflation. In 5 observations on three normal subjects, a sharp and immediate rise in blood pressure accompanied inflation of the cuffs (Figure 1).
The pulse contour changed in a manner consistent with increased peripheral resistance, i.e., the dicrotic notch occurred higher on the curve (Figure 2). A summary of the data on arterial blood pressure is shown in Table VI.

TABLE VI

Blood pressure rise with application of occluding cuffs

\begin{tabular}{|c|c|c|c|c|c|c|}
\hline \multirow[t]{2}{*}{$\begin{array}{l}\text { IISub- } \\
\text { i ject }\end{array}$} & \multirow{2}{*}{$\begin{array}{c}\begin{array}{c}\text { Maxi- } \\
\text { mum } \\
\text { resting } \\
\text { varia- } \\
\text { tion* }\end{array} \\
m m . H g\end{array}$} & \multirow{2}{*}{$\begin{array}{c}\begin{array}{c}\text { Maxi- } \\
\text { mum } \\
\text { rise in } \\
\text { systolic } \\
\text { pressure }\end{array} \\
\mathrm{mm} . \mathrm{Hg}\end{array}$} & \multirow{2}{*}{$\begin{array}{c}\begin{array}{c}\text { Maxi- } \\
\text { mum } \\
\text { rise in } \\
\text { diastolic } \\
\text { pressure }\end{array} \\
\mathrm{mm} . \mathrm{Hg}\end{array}$} & \multirow{2}{*}{$\begin{array}{c}\begin{array}{c}\text { Maxi- } \\
\text { mum } \\
\text { rise in } \\
\text { level of } \\
\text { dicrotic } \\
\text { notch }\end{array} \\
m m . \mathrm{Hg}\end{array}$} & \multicolumn{2}{|c|}{ Duration of rise } \\
\hline & & & & & Beats & Seconds \\
\hline $\begin{array}{l}\text { EK } \\
\text { EK } \\
\text { EK } \\
\text { KAM } \\
\text { G }\end{array}$ & $\begin{array}{l}4 \\
7 \\
8 \\
5 \\
7\end{array}$ & $\begin{array}{r}10 \\
5 \\
5 \\
15 \\
9\end{array}$ & $\begin{array}{r}21 \\
14 \\
6 \\
16 \\
6\end{array}$ & $\begin{array}{r}24 \\
8 \\
12 \\
20 \\
5\end{array}$ & $\begin{array}{r}3 \\
3 \\
3 \\
>6 \\
5\end{array}$ & $\begin{array}{l}2.7 \\
2.7 \\
3 \\
? \\
3.7\end{array}$ \\
\hline
\end{tabular}

* Systolic and diastolic.

The venous pressure in the femoral vein proximal to the cuff fell during the period of occlusion (Table III). A typical curve is shown in Figure 4. At the instant of cuff inflation a momentary rise in femoral vein pressure occurred, which was apparently caused by the impact of the occluding cuff.

That some redistribution of blood had occurred is shown by the fact that in one normal subject, in each of 3 tests, the venous pressure in the antecubital vein rose during the period of lower limb occlusion only to drop again when the occlusion was released.

In the four patients with thromboangiitis obliterans only 2 out of 10 tests resulted in slowing 


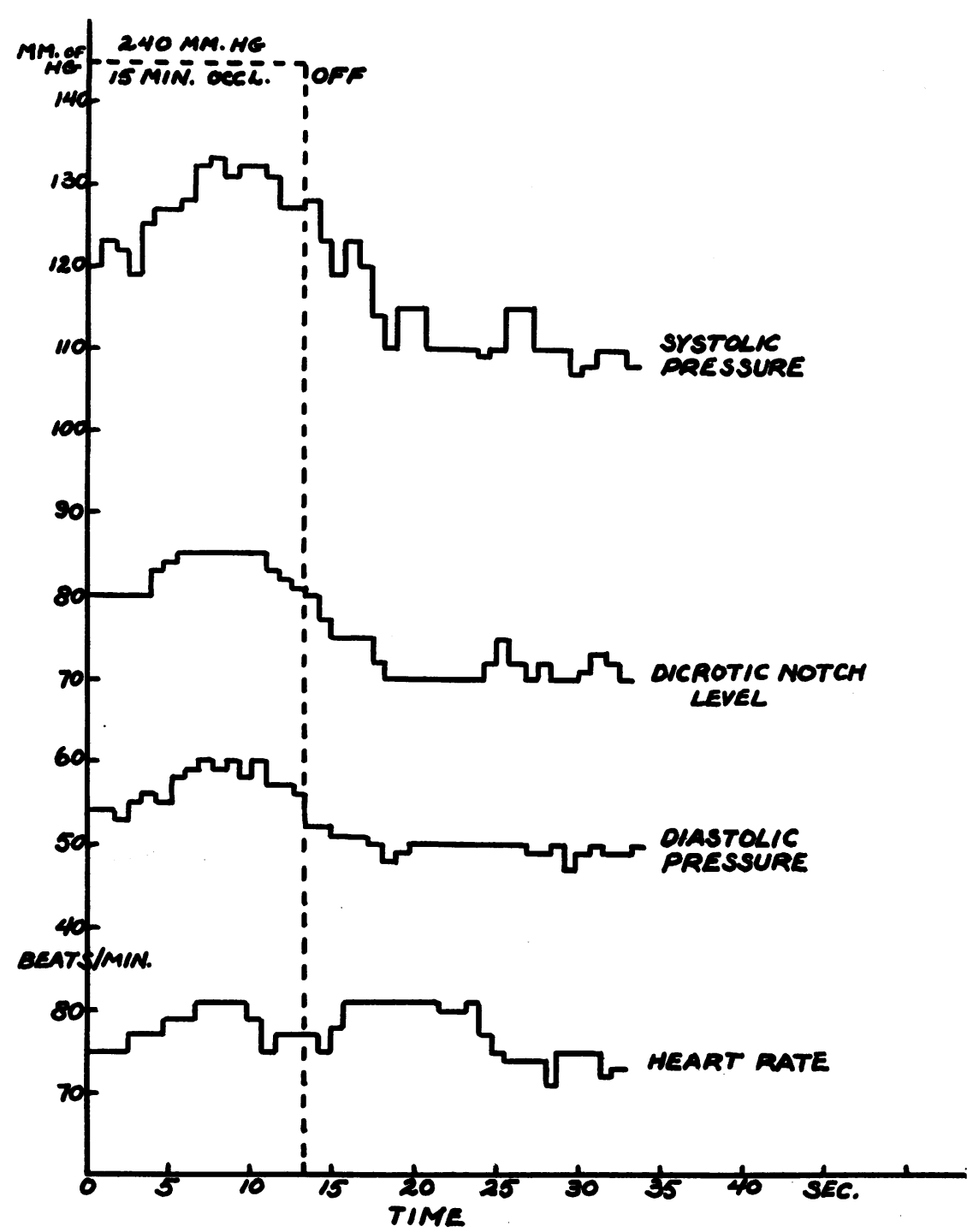

Fig. 7. The Effect on Blood Pressure and Heart Rate of Release of Bilateral Arterial Occlusion of the Lower Extremities in a Patient With Thromboangittis Obliterans

The blood pressure was recorded with the Hamilton needle manometer in the brachial artery and the heart rate with the electrocardiograph at camera speed of $2.5 \mathrm{~cm}$. per second. Note that the fall in pressure on release is more gradual than in the normal subject ( $c f$. Figure 2) and that no significant rise in heart rate occurs.

of the pulse on application of arterial occlusion. Figure 5 shows a negative experiment.

\section{DISCUSSION AND INTERPRETATION OF RESULTS}

Cardiac acceleration uniformly followed release of arterial occluding cuffs in normal subjects. This was preceded by a fall in brachial blood pressure (Figure 1). The fall in blood pressure and the change in pulse contour (Figure 2) demon- strate the presence of a low-resistance path or shunt opened up on release of the constricting cuffs. When tissues are acutely deprived of blood, vascular dilatation occurs (19). There is therefore no need to suppose "pressor-sensitive zones" in the limb vessels initiating a depressor reflex, as postulated by Asmussen et al. (3 to 9). The pressure drop is apparently the result of the passage of blood into and through the dilated ves- 
sels, the effect of this created path of low resistance being similar to that observed on releasing an $A-V$ aneurysm $(11,18,20)$. Lewis and Grant (19) have shown that the longer the period of vascular occlusion, the more marked and persistent is the reactive hyperemia on release. Table II shows the greater fall in pressure noted upon release of the more prolonged occlusions, which is consistent with this relationship. The fact that the cardiac acceleration (Figure 3), like the blood pressure drop, varies with the duration of prior occlusion, reinforces the hypothesis that the local vascular dilatation of reactive hyperemia is the initiating mechanism for both.

The time interval between the fall in blood pressure and the onset of cardiac acceleration (Table II) would permit a reflex acceleration to be initiated. This might arise in the end organs of the buffer nerves of the large vessels (viz., root of aorta and carotid sinus) or from end organs in vessels or tissues of the limbs themselves. The time interval is, however, too short to permit the possibility that metabolites carried in the blood from the limbs might stimulate end organs in the arterial tree, the pacemaker of the heart, or central nervous system cardioregulatory centers. These mechanisms can thus be excluded. In like manner, a Bainbridge or allied reflex appears to be excluded.

Since the venous pressure rise occurred after the pulse acceleration had begun (Figure 4), it cannot be the initiating mechanism for the pulse acceleration. On similar ground, neither can an increased venous return to the heart be responsible. In line with this conclusion is the fact that venous pressure changes of similar magnitude occur during respiration without any significant change in heart rate. The possibility cannot, however, be excluded that the venous pressure rise and increased venous return contribute to maintaining the pulse acceleration. There is also the possibility that a volume increase might appear in the veins earlier than a detectable rise in pressure and cause the pulse acceleration, but this seems unlikely.

Results in two subjects with incomplete release of occlusion further support the view that the sudden opening of a by-path into which blood can flow will drop the systemic arterial pressure and so bring about the accelerator reflex. It was found that deflation to above diastolic pressure levels failed to evoke cardiac acceleration, but deflation to below diastolic pressure levels resulted in an acceleration. In both cases pressure changes were transmitted to the distal limb, but in the former case no appreciable blood inflow occurred, and no acceleration was observed. This is evidence against the activity of local "pressor-sensitive zones." In the latter instance, when deflation to lowerthan-diastolic pressure resulted in cardiac acceleration, congestion of the limb was produced. This is evidence indicating that an augmentation of venous return to the heart is not essential for the pulse acceleration.

It has been shown by Lewis and Grant (19) that venous occlusion, like arterial, will cause reactive hyperemia, but of lesser degree. In keeping with this, cardiac acceleration was observed to follow release of venous occlusion in 13 experiments on four subjects, but this was less in degree than that following arterial occlusion. However, the magnitude was masked by the discomfort of limb congestion, which in itself resulted in an acceleration during occlusion, except in those subjects who were exceptionally well trained.

The fact that no significant acceleration was observed in subjects who had thromboangiitis obliterans indicates again that the primary factor in the production of cardiac acceleration is the presence of a blood pathway of low resistance. In these subjects, whether or not dilatation is present or is produced by a period of arterial occlusion, the compromised arterial lumen is a fixed factor limiting the blood inflow (17), maintaining a high total resistance, and preventing the augmentation of inflow normally observed to follow dilating procedures $(14,16)$.

When the occluding cuffs were inflated, the results were not exactly the reverse of those observed upon release of occlusion. On application of occlusion, the situation differs from that encountered in compressing an A-V aneurysm. Since occlusions were usually applied during resting states, the effect was not that of blocking an augmented circulation through a dilated system or shunt. Further, some tendency to cardiac acceleration may be ascribed to the sensation of cuff inflation. When dilation or a by-path was present at the time of application of occlusion, induced either by heat or by re-occluding during a period of reactive hyperemia, the cardiac slowing was 
apparent. The change in arterial pressure reflected in direction and in contour (Figure 2) an increase in peripheral resistance. Consistent, too, is the observation that the subjects with thromboangiitis obliterans had a reduced or absent response to this manoeuver.

\section{CONCLUSIONS}

1. The phenomena associated with the application and release of constricting tourniquets were observed.

2. Cardiac acceleration followed release of occluding cuffs about the lower extremities in normal subjects. This was absent or reduced in patients with thromboangiitis obliterans.

3. A fall in the blood pressure in the brachial artery preceded the cardiac acceleration.

4. The fall in blood pressure was caused by the opening of a temporary low resistance pathway for blood through the dilated vessels resulting from the previous occlusion of the limbs.

5. Evidence is cited to prove that the primary mechanism inducing the cardiac acceleration is a reflex response to the drop in pressure in the central arteries (Marey's Law).

6. The evidence presented also indicates that the cardiac acceleration is not caused by a metabolite accumulating in the constricted extremities; that it is not satisfied by the assumption that the reflex arises from the occluded vessel or from the tissue of the extremity.

\section{BIBLIOGRAPHY}

1. Alam, M., and Smirk, F. H., Observations in man upon a blood pressure raising reflex arising from the voluntary muscles. J. Physiol., 1937, 89, 372.

2. Alam, M., and Smirk, F. H., Observations in man on a pulse-accelerator reflex from the voluntary muscles of the legs. J. Physiol., 1938, 92, 167.

3. Asmussen, E., Christensen, E. H., and Nielsen, M., On the influence on pulse rate of alterations of arterial blood pressure. Skandinav. Arch. f. Physiol., 1938, 79, 32.

4. Idem, Influence of blood distribution on circulation and physical exercise. Ibid., 1939, 81, 185.

5. Idem, Posture and pulse rate. Ibid., 1939, 81, 190.

6. Idem, The effect on blood pressure regulation of various postures. Ibid., 1939, 81, 204.

7. Idem, On the circulatory insufficiency in the standing posture with normal arterial pressure and reduced minute-volume. Ibid., 1939, 81, 214.

8. Idem, The significance of posture on pulse rate with exercise. Ibid., 1939, 81, 224.

9. Idem, The regulation of the circulation in different postures. Surgery, 1940, 8, 604.

10. Hamilton, W. F., Brewer, J., and Brotman, I., Pressure pulse contours in the intact animal. Am. J. Physiol., 1934, 107, 427.

11. Holman, E., The anatomic and physiologic effects of an arteriovenous fistula. Surgery, 1940, 8, 362.

12. Jarisch and Gaisböck, Concerning the state of the circulation in reactive hyperemia. Arch. f. exper. Path. u. Pharmakol., 1929, 139, 159.

13. Krogh, A., Effect of posture on the regulation of the circulation. Proc. Inst. Med. Chicago, 1939, 12, 398.

14. Kunkel, P., and Stead, E. A., Jr., Blood flow and vasomotor reactions in the foot in health, in arteriosclerosis and in thromboangiitis obliterans. J. Clin. Invest., 1938, 17, 715.

15. Landowne, M., Simple apparatus for optical registration of vascular dynamics. Am. J. Physiol., 1941, 133, 359.

16. Landowne, M., and Katz, L. N., A critique of the plethysmographic method of measuring blood flow in the extremities of man. Am. Heart J. (In press.)

17. Landowne, M., Dynamics of blood flow in thromboangiitis obliterans. (Unpublished.)

18. Lewis, D., Libman Anniversary Volume. The bradycardiac reaction and the cardiac changes in arteriovenous aneurisms. International Press, New York. 1932, II, 733.

19. Lewis, T., and Grant, R., Observations upon reactive hyperemia in man. Heart, 1925, 12, 73.

20. McGuire, J., Hauenstein, V., Stevens, C. D., and Sharrets, K. C., Effects of arteriovenous fistulae on the heart and circulation. Blood, Heart and Circulation, Publication No. 13 of Amer. Assoc. Advancement Sci., 1940, p. 213. 